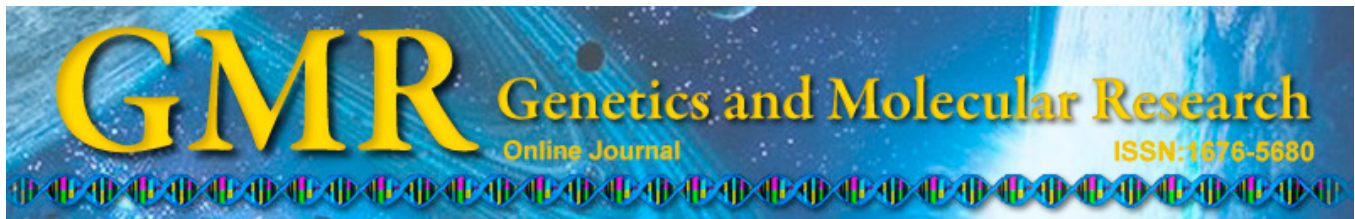

\title{
Phylogeny of Marmosops and the occurrence of Marmosops pinheiroi (Pine, 1981) (Didelphimorphia, Didelphidae) in the Cerrado savanna of Maranhão, Brazil
}

D.C. Nascimento ${ }^{1,2}$, A.P.M. Olímpioº ${ }^{2}$ E. Conceição ${ }^{2}$, B.A.T.P. Campos ${ }^{4}$, E.C. Fraga ${ }^{1,2,3}$ and M.C. Barros ${ }^{1,2,3}$

${ }^{1}$ Programa de Pós-Graduação em Ciência Animal, Centro de Ciências Agrárias, Universidade Estadual do Maranhão, São Luís, MA, Brasil

${ }^{2}$ Laboratório de Genética e Biologia Molecular,

Centro de Estudos Superiores de Caxias, Universidade Estadual do Maranhão, Caxias, MA, Brasil

${ }^{3}$ Programa de Pós-Graduação em Biodiversidade, Ambiente e Saúde,

Centro de Estudos Superiores de Caxias, Universidade Estadual do Maranhão, Caxias, MA, Brasil

${ }^{4}$ Programa de Pós-Graduação em Zoologia,

Centro de Ciências Exatas e da Natureza, Universidade Federal da Paraíba,

João Pessoa, PB, Brasil

Corresponding author: M.C. Barros

E-mail: mbdene@yahoo.com.br

Genet. Mol. Res. 14 (1): 304-313 (2015)

Received May 24, 2014

Accepted September 25, 2014

Published January 23, 2015

DOI http://dx.doi.org/10.4238/2015.January.23.4

ABSTRACT. The present study reviews the phylogeny of the genus Marmosops and expands the geographic range of Marmosops pinheiroi to the Brazilian State of Maranhão. Five specimens of M. pinheiroi were collected from the Inhamum Municipal Environmental Protection Area in Caxias, Maranhão. Total DNA was extracted and the mitochondrial cytochrome $b$ gene was sequenced in an ABI PRISM 3500. Additional sequences of 
Marmosops were obtained from GenBank for specimens from southeastern and northeast Brazil and the northern Amazon Forest. The results of the analysis indicated that $M$. incanus and M. paulensis form a well-supported clade, and that M. pinheiroi, M. pakaraimae, and M. parvidens are sister groups, with $71 \%$ support. The $M$. pinheiroi specimens from different regions grouped with high bootstrap values (99 and 100\%). Interspecific genetic divergence varied from 8.3 to $21.5 \%$, while intraspecific divergence ranged from 0.2 to $6.3 \%$ in $M$. pinheiroi, 0.3 to $2.9 \%$ in M. parvidens, and 0.4 to $6.9 \%$ in $M$. incanus. Given the taxonomic complexity of the genus, the results of the present study offer important insights into the taxonomic status of M. pinheiroi, as well as extend its known distribution $670 \mathrm{~km}$ south and east to the Brazilian State of Maranhão.

Key words: Genetic diversity; Genetic variability; Maranhão; Marsupial; Marmosops pinheiroi; Phylogeny

\section{INTRODUCTION}

A total of 16 Marmosops species are currently recognized, and with the exception of Marmosops invictus, which is endemic to Panama, all known species are found in South America (Gardner, 2008; Voss et al., 2013). In Brazil, nine species are known to be present in the country's different terrestrial biomes (Paglia et al., 2012) - Atlantic Forest (Marmosops paulensis and Marmosops incanus), Cerrado (M. incanus and Marmosops ocellatus), Caatinga (M. incanus), Pantanal (M. ocellatus), and the Amazon Forest (Marmosops bishopi, Marmosops impavidus, Marmosops neblina, Marmosops noctivagus, Marmosops parvidens, and Marmosops pinheiroi).

The nomenclature of the taxon M. pinheiroi has undergone a series of modifications, being described initially as a subspecies (Marmosops parvidens pinheiroi) of the M.parvidens complex by Pine (1981). More recently, Voss et al. (2001) elevated this taxon to a full species. M. pinheiroi is found in the northern Amazon basin, ranging from southeastern Venezuela to the north of the Brazilian state of Pará (Gardner, 2008), in areas where two other species - $M$. parvidens and Marmosops pakaraimae - may also occur (Voss et al., 2013).

The species M. pinheiroi, M. parvidens, and M. pakaraimae share a lateral tubercule on the carpus, which differentiates them from other members of the genus. However, they are also differentiated from one another by other morphological characteristics. In particular, $M$. pinheiroi is characterized by a grayish-brown pelage, taller canines, a wider cranium and more accentuated lachrymals, whereas $M$. parvidens has reddish pelage, shorter canines, a narrower cranium, and reduced lachrymals; M. pakarainae has dark brown pelage and mean craniodental measurements higher than those of other species (Voss et al., 2001, 2013).

However, while $M$. pinheiroi is well differentiated morphologically from the other species of the genus, traditional taxonomic approaches have not been conclusive in determining its species status (Dayrat, 2005). The small neotropical marsupials are an especially poorly-known group, specifically in regard to the delimitations of species ranges (Miranda et al., 2005). The use of molecular data, in particular DNA barcodes, has become increasingly important for the identification of species in taxonomic studies (Hebert et al., 2004). In the specific case of the didelphids, the mitochondrial cytochrome oxidase I (COI) and cytochrome 
$b$ genes have been extremely effective for species determination (Agrizzi et al., 2012).

Cytochrome $b$ is widely used in phylogenetic studies of vertebrates, and the evolutionary and biochemical dynamics of the protein encoded by this gene are well understood. Divergence in this gene, associated with sister species, congeners, and confamilial genera, is phylogenetically informative, with a reduced likelihood of saturation in the substitution of nucleotides (Meyer, 1994; Russo et al., 1996; Johns and Avise, 1998). Gutiérrez et al. (2010) considered molecular data to be especially useful for the evaluation of the monophyly of species that are well-defined morphologically, in order to evaluate intraspecific genetic divergence; this have provided reliable support for the majority of the clades of sister species in the genera Micoureus and Marmosa.

Molecular analyses of the phylogenetic relationships among Marmosops species have focused on populations from southeastern Brazil, the western Amazon basin, the Guyanas, and Bolivia (Mustrangi and Patton, 1997; Patton et al., 2000; Voss et al., 2001, 2004b), but none of these studies have included specimens from the Brazilian State of Maranhão. In the present study, based on the analysis of the cytochrome $b$ gene, we expanded the geographic distribution of $M$. pinheiroi to include Maranhão, and the phylogenetic relationships between this species and its congeners that occur within the same geographic region, with the primary aim of ensuring the correct identification of the different species.

\section{MATERIAL AND METHODS}

Specimens were collected in the Inhamum Municipal Environmental Protection Area (Inhamum MEPA) using pitfall traps between July, 2010 and January, 2012. This conservation unit has a total area of 4500 hectares (Barros, 2012), and is located in the central-eastern portion of the Brazilian State of Maranhão, adjacent to the BR-316 federal highway, approximately $2 \mathrm{~km}$ from the urban perimeter of the municipality of Caxias, Maranhão $4^{\circ} 53^{\prime} 30^{\prime \prime} \mathrm{S}$, $\left.43^{\circ} 24^{\prime} 53^{\prime \prime} \mathrm{W}\right)$. The vegetation is typical of the Cerrado savanna, with two main strata, one arboreal/shrubby and the other grassy on the flatter terrain, and dense stands of buriti palm in the depressions, accompanying the local water courses (Neres and Conceição, 2010).

The DNA was extracted from muscle tissue using the standard phenol-chloroform protocol described by Sambrook and Russel (2001). The cytochrome $b$ gene was amplified by polymerase chain reaction (PCR) using the forward primer MVZ05 (5'-CGAAGCTTGATATGAAAAACCATCGTTG-3') and the reverse primer MVZ16 (5'AAATAGGAARTATCAYTCTGGTTTRAT-3') (Smith and Patton, 1993) under the following PCR regime: $94^{\circ} \mathrm{C}$ for $3 \mathrm{~min}$, followed by 30 cycles of $94^{\circ} \mathrm{C}$ for $1 \mathrm{~min}, 45^{\circ} \mathrm{C}$ for $1 \mathrm{~min}, 72^{\circ} \mathrm{C}$ for $2 \mathrm{~min}$, and a final cycle of $72^{\circ} \mathrm{C}$ for $10 \mathrm{~min}$. PCR products were purified using enzymes ExoProStar 1-Step (GE Healthcare) according to the manufacturer protocol, and cycle sequenced using BigDye Terminator 3.1 (Applied Biosystems) during 30 cycles of $96^{\circ} \mathrm{C}$ for $15 \mathrm{~s}, 50^{\circ} \mathrm{C}$ for $15 \mathrm{~s}, 60^{\circ} \mathrm{C}$ for $4 \mathrm{~min}$. After precipitation in EDTA/sodium acetate/ethanol, the product was sequenced using an automated capillary sequencer ABI 3500/Life Technologies (Applied Biosystems).

The sequences were aligned using ClustalW (Thompson et al., 1994) using standard parameters, and then converted into the Fasta format. Where necessary, the sequence was adjusted using the BioEdit sequence editor, version 7.0.5.2 (Hall, 1999). Nucleotide saturation was evaluated through plots of transitions and transversions with the Tamura-Nei distance parameter in DAMBE, version 5 (Xia, 2013). The evolutionary model that was best adjusted 
to the data, phylogenetic reconstructions based on the maximum likelihood (ML), maximum parsimony (MP), and neighbor-joining (NJ) approaches, and the matrix of genetic divergence were obtained in MEGA 6.0 (Tamura et al., 2013). Bootstrap support (Felsenstein, 1985) was obtained through an analysis with 1000 replications.

\section{RESULTS}

A total of five specimens of M. pinheiroi were collected in the Inhamum MEPA (Table 1). For molecular analyses, a 737 base pair (bp) fragment was obtained from each of these five specimens and a further 34 sequences were obtained from GenBank, including eight from $M$. pinheiroi and 26 from M. pakaraimae, M. incanus, M. paulensis, and M. parvidens. The phylogenetic analyses were based on the haplotypes, and the matrix of genetic divergence was organized in groups, with means being calculated for the divergence within and between groups (Table 2).

Table 1. Details of the Marmosops pinheiroi specimens collected in the Inhamum Municipal Environmental Protection Area, Caxias, MA, Brazil.

\begin{tabular}{|c|c|c|c|c|c|c|}
\hline Voucher & Date of collection & Age/Sex & $\mathrm{TL}$ & TA & HL & HBL \\
\hline UFPB 9037 & $08 / 03 / 11$ & Adulto ${ }^{\wedge}$ & 235 & 135 & 32 & 100 \\
\hline UFPB 9011 & $18 / 07 / 11$ & Jovem $\hat{\delta}$ & 182 & 105 & 30 & 77 \\
\hline UFPB 9012 & $16 / 07 / 11$ & Jovem $\widehat{\delta}$ & 190 & 100 & 28 & 90 \\
\hline UFPB 9040 & $08 / 09 / 11$ & Jovem $\widehat{\partial}$ & 195 & 110 & 28 & 85 \\
\hline UFPB 9097 & $19 / 10 / 11$ & Adulto $\widehat{0}$ & 220 & 135 & 25 & 85 \\
\hline
\end{tabular}

$\mathrm{TL}=$ total length $(\mathrm{mm}) ; \mathrm{TA}=$ tail length $(\mathrm{mm}) ; \mathrm{HL}=$ head length $(\mathrm{mm}) ; \mathrm{HBL}=$ length of head-and-body $(\mathrm{mm})$.

Table 2. Localities and access numbers of the Marmosops specimens analyzed in the present study.

\begin{tabular}{|c|c|c|c|}
\hline Species (haplotypes) & Locality & Coordinates & GenBank accession Nos. \\
\hline M. pinheiroi & Maranhão, BR & $4^{\circ} 53^{\prime} \mathrm{S}, 43^{\circ} 24^{\prime} \mathrm{W}$ & - \\
\hline M. pinheiroi & Maranhão, BR & $4^{\circ} 53^{\prime} \mathrm{S}, 43^{\circ} 24^{\prime} \mathrm{W}$ & - \\
\hline M. pinheiroi & Maranhão, BR & $4^{\circ} 53^{\prime} \mathrm{S}, 43^{\circ} 24^{\prime} \mathrm{W}$ & - \\
\hline M. pinheiroi & Pará, BR & $3^{\circ} 39^{\prime} \mathrm{S}, 52^{\circ} 22^{\prime} \mathrm{W}$ & KC954765 \\
\hline M. pinheiroi & Guiana & $4^{\circ} 44^{\prime} \mathrm{N}, 58^{\circ} 43^{\prime} \mathrm{W}$ & KC954763 \\
\hline M. pinheiroi & Guiana & $4^{\circ} 17^{\prime} \mathrm{N}, 58^{\circ} 31^{\prime} \mathrm{W}$ & AJ606433 \\
\hline M. pinheiroi & Suriname & $2^{\circ} 02^{\prime} \mathrm{N}, 56^{\circ} 08^{\prime} \mathrm{W}$ & KC954766 \\
\hline M. pinheiroi & Suriname & $4^{\circ} 29^{\prime} \mathrm{N}, 57^{\circ} 02^{\prime} \mathrm{W}$ & KC954764 \\
\hline M. pinheiroi & Suriname & $5^{\circ} 08^{\prime} \mathrm{N}, 55^{\circ} 29^{\prime} \mathrm{W}$ & AJ606432 \\
\hline M. pinheiroi & French Guiana & $4^{\circ} 05^{\prime} \mathrm{N}, 52^{\circ} 40^{\prime} \mathrm{W}$ & AJ606430 \\
\hline M. parvidens & Suriname & $4^{\circ} 56^{\prime} \mathrm{N}, 55^{\circ} 12^{\prime} \mathrm{W}$ & AJ606427 \\
\hline M. parvidens & Suriname & $4^{\circ} 56^{\prime} \mathrm{N}, 55^{\circ} 12^{\prime} \mathrm{W}$ & AJ606429 \\
\hline M. parvidens & Suriname & $4^{\circ} 33^{\prime} \mathrm{N}, 57^{\circ} 04^{\prime} \mathrm{W}$ & KC954759 \\
\hline M. parvidens & Suriname & $4^{\circ} 56^{\prime} \mathrm{N}, 55^{\circ} 12^{\prime} \mathrm{W}$ & AJ606428 \\
\hline M. parvidens & French Guiana & $5^{\circ} 17^{\prime} \mathrm{N}, 52^{\circ} 55^{\prime} \mathrm{W}$ & AJ606426 \\
\hline M. parvidens & French Guiana & $4^{\circ} 51^{\prime} \mathrm{N}, 53^{\circ} 04^{\prime} \mathrm{W}$ & AJ606423 \\
\hline M. parvidens & French Guiana & $5^{\circ} 17^{\prime} \mathrm{N}, 52^{\circ} 55^{\prime} \mathrm{W}$ & KC954761 \\
\hline M. parvidens & Guiana & $3^{\circ} 45^{\prime} \mathrm{N}, 59^{\circ} 18^{\prime} \mathrm{W}$ & AJ606424 \\
\hline M. incanus & Rio de Janeiro, BR & $22^{\circ} 57^{\prime} \mathrm{S}, 44^{\circ} 02^{\prime} \mathrm{W}$ & КC954771 \\
\hline M. incanus & Espírito Santo, BR & $20^{\circ} 28^{\prime} \mathrm{S}, 40^{\circ} 52^{\prime} \mathrm{W}$ & GU112906 \\
\hline M. incanus & Espírito Santo, BR & $19^{\circ} 23 \mathrm{~S}, 40^{\circ} 79^{\prime} \mathrm{W}$ & GU112903 \\
\hline M. incanus & Espírito Santo, BR & $19^{\circ} 96^{\prime} \mathrm{S}, 40^{\circ} 54^{\prime} \mathrm{W}$ & GU112902 \\
\hline M. incanus & Minas Gerais, BR & $17^{\circ} 13^{\prime} \mathrm{S}, 42^{\circ} 76 \mathrm{~W}$ & GU112905 \\
\hline M. incanus & Minas Gerais, BR & $20^{\circ} 08^{\prime} \mathrm{S}, 43^{\circ} 50^{\prime} \mathrm{W}$ & GU112900 \\
\hline M. incanus & Bahia, BR & $12^{\circ} 80^{\prime} \mathrm{S}, 41^{\circ} 26 \mathrm{~W}$ & GU112904 \\
\hline M. pakaraimae & Guiana & $5^{\circ} 07^{\prime} \mathrm{N}, 59^{\circ} 49^{\prime} \mathrm{W}$ & KC954770 \\
\hline M. paulensis & Rio de Janeiro, BR & $22^{\circ} 24^{\prime} \mathrm{S}, 57^{\circ} 59^{\prime} \mathrm{W}$ & KF313983 \\
\hline
\end{tabular}


Overall, 278 sites were variable, of which 247 were information for parsimony analysis. Haplotype diversity was 0.98 , and nucleotide diversity, 0.12 , and there was no evidence of saturation in the transition/transversion plot. The Tamura-Nei model was the most relevant here, with a discrete gamma distribution, considering the five taxa as categories and assuming that a certain proportion of the sites are evolutionarily invariable $(\mathrm{TN} 93+\mathrm{G}+\mathrm{I})$. The same topology was obtained for all the different approaches (Figure 1), with bootstrap values of over 50\% at most nodes. The species Gracilinanus agilis (KF313981) and Thylamys pusillus (HM583419) were used as the outgroup owing to the fact that their relationships had been reconstructed in previous studies of didelphimorph phylogeny (Voss and Jansa, 2009).

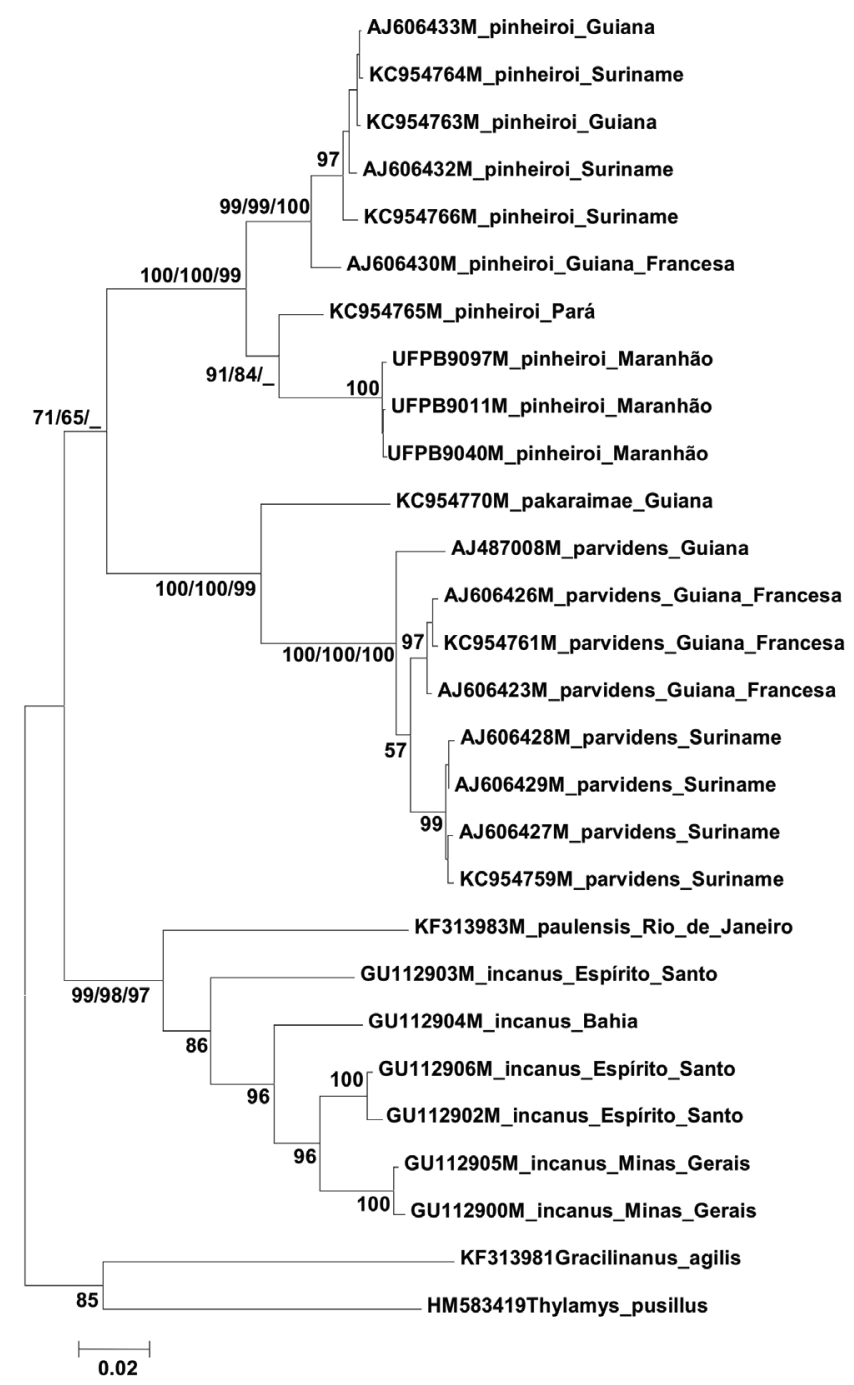

Figure 1. Phylogenetic tree obtained by neighbor-joining analysis using the Tamura-Nei parameter for Marmosops specimen cytochrome b sequences, with bootstrap values for the ML/NJ/MP methods (left to right). 
The phylogenetic trees reveal a well-supported (99/98/97\%) clade between M. incanus and M. paulensis. The species M. pinheiroi, M. pakaraimae, and M. parvidens appear as sister groups, with $71 \%$ bootstrap support. However, whatever the locality or the method used, the $M$. pinheiroi specimens form a strongly supported (bootstrap scores of 99 and 100\%) monophyletic group, as observed in the sister group formed by M. pakaraimae and M. parvidens (Figure 1).

Interspecific genetic divergence varied between 8.3 and $21.5 \%$ (Table 3), with the lowest value being recorded between M. pakaraimae and M. parvidens, both from the Guyanas, and the maximum values being found between M. pinheiroi from Maranhão and $M$. incanus from Minas Gerais, with a mean value of $14.6 \%$. Intraspecific divergence in $M$. pinheiroi ranged from 0.2 to $6.2 \%$, with the lowest values being recorded among the specimens from Maranhão, and the highest between those from Maranhão and French Guiana. Intraspecific divergence varied from 0.3 to $2.9 \%$ in M.parvidens and from 0.4 to $6.9 \%$ in M. incanus. While the intraspecific divergence recorded in $M$. pinheiroi was as high as $6.3 \%$, it was consistent with that found in M. incanus, and lower than the values for interspecific divergence involving this species.

Table 3. Matrix of genetic divergence (group means) for the Marmosops species analyzed in the present study, based on sequences of the mitochondrial cytochrome $b$ gene, using the Tamura-Nei parameter.

\begin{tabular}{lrrrrrrrrrrrrrrr}
\hline & {$[1]$} & \multicolumn{1}{c}{$[2]$} & \multicolumn{1}{c}{$[3]$} & \multicolumn{1}{c}{$[4]$} & \multicolumn{1}{c}{$[5]$} & \multicolumn{1}{c}{$[6]$} & {$[7]$} & {$[8]$} & {$[9]$} & {$[10]$} & {$[11]$} & {$[12]$} & {$[13]$} & {$[14]$} & {$[15]$} \\
\hline$[1]$ & $\mathbf{0 . 2}$ & & & & & & & & & & & & & \\
{$[2]$} & 4.2 & - & & & & & & & & & & & & \\
{$[3]$} & 6.0 & 5.6 & $\mathbf{0 . 3}$ & & & & & & & & & & & \\
{$[4]$} & 6.0 & 5.5 & 0.5 & $\mathbf{0 . 7}$ & & & & & & & & & & \\
{$[5]$} & 6.3 & 6.0 & 2.2 & 2.2 & - & & & & & & & & & \\
{$[6]$} & 18.0 & 16.0 & 17.0 & 17.0 & 15.9 & $\mathbf{0 . 3}$ & & & & & & & & \\
{$[7]$} & 18.0 & 15.7 & 18.0 & 18.1 & 17.4 & 2.9 & - & & & & & & & \\
{$[8]$} & 16.9 & 15.0 & 16.5 & 16.5 & 15.4 & 1.9 & 2.8 & $\mathbf{0 . 4}$ & & & & & & \\
{$[9]$} & 20.3 & 17.5 & 17.7 & 17.7 & 16.4 & 19.1 & 18.8 & 18.2 & $\mathbf{5 . 5}$ & & & & & \\
{$[10]$} & 21.5 & 18.4 & 18.9 & 19.2 & 19.0 & 19.8 & 19.1 & 19.0 & 5.4 & $\mathbf{0 . 4}$ & & & & \\
{$[11]$} & 19.1 & 16.5 & 18.3 & 18.4 & 17.0 & 19.3 & 18.1 & 18.0 & 6.9 & 5.8 & - & & & \\
{$[12]$} & 15.7 & 13.6 & 14.9 & 14.8 & 14.6 & 9.2 & 8.6 & 8.3 & 18.6 & 19.6 & 18.5 & - & & \\
{$[13]$} & 19.0 & 18.9 & 19.3 & 19.4 & 19.4 & 20.8 & 20.7 & 20.3 & 13.6 & 12.4 & 11.7 & 20.7 & - & \\
{$[14]$} & 21.3 & 18.3 & 21.4 & 20.9 & 21.5 & 23.7 & 23.4 & 23.1 & 19.8 & 20.6 & 20.2 & 20.5 & 21.7 & - \\
{$[15]$} & 19.3 & 19.2 & 17.1 & 17.1 & 18.7 & 24.3 & 23.4 & 24.0 & 25.0 & 25.9 & 22.6 & 21.9 & 21.4 & 18.9 & - \\
\hline
\end{tabular}

Number of haplotypes recorded for each group (locality) is shown within parentheses. [1] M. pinheiroi_Maranhão, Brazil (3); [2] M. pinheiroi_Pará, Brazil (1); [3] M. pinheiroi_Guyana (2); [4] M.pinheiroi_Suriname (3); [5] M. pinheiroi_French Guiana (1); [6] M. parvidens_Suriname (4); [7] M. parvidens_Guyana (1); [8] M. parvidens French Guiana (3); [9] M. incanus_Espírito Santo, Brazil (3); [10] M. incanus_Minas Gerais, Brazil (2); [11] M. incanus_Bahia, Brazil (1); [12] M. pakaraimae_Guyana (1); [13] M. paulensis_Rio de Janeiro, Brazil (1); outgroup: [14] G. agilis [15] T. pusillus. Values in the diagonal represent the intraspecific divergence for each group represented by more than one specimen.

The lowest interspecific divergence recorded in this study (8.3\%) is only two percentage points higher than the greatest intraspecific variation (6.3\%) for the $M$. pinheiroi, and even lower in the case of $M$. incanus (1.4\%), emphasizing the taxonomic complexity of the group. Despite the relatively high intraspecific divergence recorded for $M$. pinheiroi, interspecific values were much higher, ranging from $15.7 \%$ for the comparison with $M$. pakaraimae to $19.1 \%$ in the case of M. incanus.

These values, together with the results of the phylogenetic analyses, reinforce the species status of $M$. pinheiroi as indicated by the morphological data. The confirmation of the 
occurrence of the species in the Brazilian State of Maranhão represents a range extension of the order of $670 \mathrm{~km}$ (Figure 2) to the south and east of its previously known distribution.

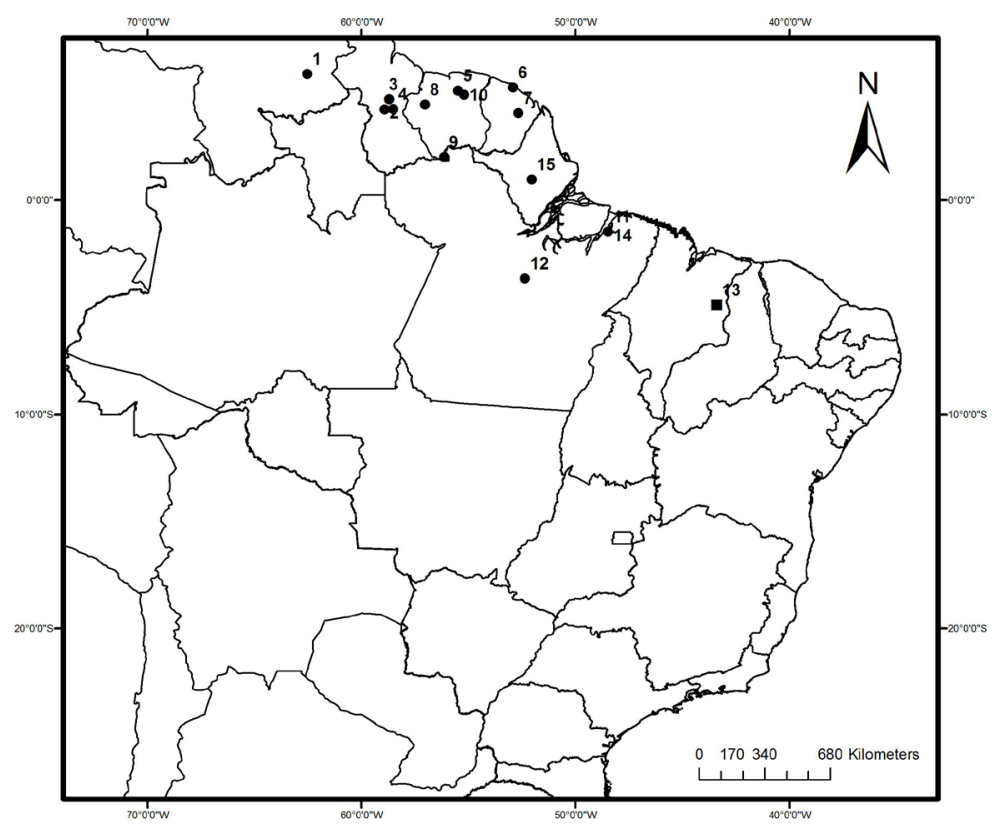

Figure 2. Map of the geographic distribution of Marmosops pinheiroi with the new record from Maranhão (Brazil) shown as a black square: 1: Bolívar, Auyán-tepui (Venezuela); 2: Potaro-Siparuni, Iwokrama Forest, Canopy Walkway (Guyana); 3: Potaro-Siparuni, Iwokrama Forest, Turtle Mountain, 10 km NW Kurupukari (Guyana); 4: Potaro-Siparuni, Iwokrama Forest, Kabukalli Landing (Guyana); 5: Brokopondo, Finisanti (Suriname); 6: Paracou (French Guiana); 7: Les Nouragues (French Guiana); 8: Sipaliwini, Bakhuis Transect 9 (Suriname); 9: Nickerie, Sipaliwini Airstrip (Suriname); 10: Brokopondo, Brownsberg Nature Park, Jeep Trail (Suriname); 11: Utinga, near Belém, Pará (Brazil); 12: 52 km SSW Altamira, Pará (Brazil); 13: Inhamum, Maranhão (Brazil); 14: Belém, Pará (Brazil); 15: Serra do Navio, Amapá (Brazil).

\section{DISCUSSION}

The current classification of the small-bodied didelphids (mouse opossum) should be considered with caution, given that the ample geographic ranges of many forms, together with the variation in their morphological characteristics, has led to the description of a number of new species (Monodelphis handleyi, Monodelphis ronaldi, M. pakaraimae, and Marmosops creightoni) in recent years, and even three new genera - Tlacuatzin, Chacodelphis, and Criptonanus (Voss and Jansa, 2003; Solari, 2003, 2007; Voss et al., 2004a,b, 2005, 2013). The phylogenetic analyses presented in this study provide a new perspective on this diversity, in particular the relationship between $M$. pinheiroi and other Marmosops populations, given that Inhamum is $670 \mathrm{~km}$ south and east of the nearest recorded locality for this species.

The mean total length of the adult specimens collected in the present study (227.5 $\mathrm{mm}$ ) was lower than that of the M. pinheiroi specimens from French Guiana, which had mean lengths of $255 \mathrm{~mm}$ in the males and $244 \mathrm{~mm}$ in the females. With lower sized about $37 \mathrm{~mm}$ length of type specimen, a male of $265 \mathrm{~mm}$ from the Serra do Navio in the Brazilian State of 
Amapá (Voss et al., 2001). Other species, such as M. pakaraimae $(270 \mathrm{~mm})$ and M. parvidens $(250 \mathrm{~mm})$, are also larger in size (Voss et al., 2013). A larger sample, together with quantitative craniodental analyses, would be necessary to define any pattern reliably.

The analysis presented here shows a strong relationship between the specimens from Maranhão and Pará, with the three northern Amazonian species forming a moderately well supported group, and M. parvidens and M. pakaraimae in a clear sister grouping, reinforcing the conclusions of Voss et al., (2013). High levels of intraspecific genetic diversity, like those found here in M. pinheiroi (6.3\%) and M. incanus (6.9\%), have been observed in other didelphids, such as Gracilinanus microtarsus (8.7\%), M. incanus (9.1\%), Caluromys philander (6.2\%), and Metachirus nudicaudatus (6.1\%) (Agrizzi et al., 2012). Patton and Costa (2003), analyzing cytochrome $b$, also found high levels of genetic divergence in the didelphids, in particular the smallest-bodied genera (Monodelphis and Marmosops), and concluded that they may represent an ancient radiation. Steiner and Catzeflis (2004) also recorded a high level of intraspecific divergence (7.2\%) in M. pinheiroi from Pará and French Guiana, analyzing a fragment of the cytochrome $b$ gene.

Like a number of other didelphids, the taxonomy of Marmosops has been the subject of a number of reviews since the classic revision of Tate (1933), and is now the second most diverse dideldimorph genus (Gardner, 2008). In the specific case of the M. parvidens complex (sensu Pine, 1981), Mustrangi and Patton (1997) found high levels of intraspecific divergence with clear differences in relation to other congener species. The molecular data presented here are important not only for the understanding of the taxonomy of M. pinheiroi, but also in understanding its genetic diversity over a wider area of distribution.

Prior to the present study, M. pinheiroi was known only from the Amazon forest, and there were no records from more open forest habitats (Gardner, 2008), although other animal species typically found in the rainforest have been recorded in the Brazilian Cerrado savanna (Lopes et al., 2007; Miranda et al., 2009). This appears to be related to the presence of gallery forests in these systems, which function as connecting corridors (Costa, 2003). In addition to these features, Inhamum is located within a transition zone, and is characterized by a mosaic of habitat types, which is reflected in a considerable heterogeneity of fauna, including amphibians and other mammals typical of the Amazon and Atlantic forests, and the Caatinga scrublands (Barros, 2012), reinforcing the value of this tract of Cerrado as a conservation area.

The geographic range of Marmosops encompasses an area that has undergone a number of important geological processes related to the uplifting of the Andes, marine transgressions, and climatic shifts over different geological epochs (Hoorn et al., 2010; Patterson et al., 2012). A more complete phylogeny based on molecular dating would help to clarify the evolutionary history of the genus, and the factors that determined the present-day distribution of the different species of the genus.

\section{ACKNOWLEDGMENTS}

We are grateful to Fundação de Amparo à Pesquisa e Desenvolvimento Científico do Maranhão (FAPEMA) for financing this study, and the students of the GENBIMOL (Genetics and Molecular Biology Laboratory, Caxias, Maranhão, Brazil) for their invaluable support in the field. Coordenação de Aperfeiçoamento de Pessoal de Nível Superior (CAPES) provided the first and fourth authors with graduate stipends. 


\section{REFERENCES}

Agrizzi J, Loss AC, Farro APC and Duda R (2012). Molecular diagnosis of Atlantic Forest mammals using mitochondrial DNA sequences: Didelphid marsupials. Open Zool. J. 5: 2-9.

Barros MC (2012). Biodiversidade na Área de Proteção Ambiental Municipal do Inhamum. 1st edn. UEMA, São Luís.

Costa LP (2003). The historical bridge between the Amazon and the Atlantic Forest of Brazil: a study of molecular phylogeography with small mammals. J. Biogeogr. 30: 71-86.

Dayrat B (2005). Towards integrative taxonomy. Biol. J. Linn. Soc. 85: 407-415.

Felsenstein J (1985). Confidence limits on phylogenies: An approach using the bootstrap. Evolution 39: 783-91.

Gardner AL (2008). Mammals of South America. Vol. 1. Marsupials, Xenarthrans, Shrews, and Bats. Chicago University Press, Chicago, 669.

Gutiérrez EE, Jansa SA and Voss RS (2010). Molecular systematics of mouse opossums (Didelphidae: Marmosa): Assessing species limits using mitochondrial DNA sequences, with comments on phylogenetic relationships and biogeography. Am. Mus. Nat. Hist. 3692: 1-22.

Hall TA (1999). BioEdit: a user-friendly biological sequence alignment editor and analysis program for Windows 95/98/ NT. Nucl. Acids Symp. Ser. 41: 95-98.

Hebert PDN, Penton EH, Burns JM, Janzen DH, et al. (2004). Ten species in one: DNA barcoding reveals cryptic species in the neotropical skipper butterfly Astraptes fulgerator. Proc. Natl. Acad. Sci. 101: 14812-14817.

Hoorn C, Wesselingh FP, ter Steege H and Bermudez MA (2010). Amazonian through time: Andean uplift, climate change, landscape evolution, and biodiversity. Science 330: 927-931.

Johns GC and Avise JC (1998). A comparative summary of genetic distances in the vertebrates from the mitochondrial cytochrome b gene. Mol. Biol. Evol. 15: 1481-1490.

Lopes FM, Carvalho ST and Santos MPD (2007). Extensão de distribuição da pipira-da-taoca (Eucometis penicillata) para o estado do Piauí e leste do Maranhão. Brasil. Atualid. Ornitol. 137: 40-41.

Meyer A (1994). Shortcomings of the cytochrome b gene as a molecular marker. Trends Ecol. Evol. 9: 278-280.

Miranda CL, Lima MGM, Santos MPD and Silva Júnior JS (2005). Ocorrência de Micoureus demerarae (Thomas, 1905) no estado do Piauí, Brasil. Publ. Avulsas Conserv. Ecossistemas 2: 1-4.

Miranda CL, Rossi RV, Silva Júnior JS and Lima MGM (2009). Mammalia, Didelphimorphia, Didelphidae, Metachirus nudicaudatus, Municipality of José de Freitas, State of Piauí, Northeastern Brazil: distribution extension. CheckList 5: 360-363.

Mustrangi MA and Patton JL (1997). Phylogeography and systematics of the slender mouse opossum Marmosops (Marsupialia, Didelphidae). Univ. Calif. Publ. Zool. 130: 86.

Neres LP and Conceição GM (2010). Florística e fitossociologia da Área de Proteção Ambiental Municipal do Inhamum, Caxias, Maranhão, Brasil. Cad. Geocienc. 7: 122-130.

Paglia AP, Fonseca GAB, Rylands AB, Herrmann G, et al. (2012). Lista Anotada dos Mamíferos do Brasil. Conserv. Internat, Occas Papers Conserv. Biol. 2nd edn. n. 6, 82.

Patterson BD, Solari S and Velazco PM (2012). The Role of the Andes in the Diversification and Biogeography of Neotropical Mammals. In: Bones, Clones, and Biomes: The history and Geography of Recent Neotropical Mammals (Patterson BD and Costa LP, eds.). University Chicago Press, Chicago, 351-378.

Patton JL, Silva MNF and Malcolm JR (2000). Mammals of the Rio Juruá and the evolutionary and ecological diversification of Amazonia. Bull. Am. Mus. Nat. Hist. 244: 1-306.

Patton JL and Costa LP (2003). Molecular Phylogeography and Species Limits in Rainforest Didelphid Marsupials of South America. In: Predators With Pouches: the Biology of Carnivorous Marsupials (Jones M, Dickiman C and Archer M, eds.). CSIRO Publishing, Melbourne, 21-29.

Pine RH (1981). Reviews of the mouse opossums Marmosa parvidens Täte and Marmosa invicta Goldman (Mammalia: Marsupialia: Didelphidae) with description of a new species. Mammalia 45: 55-70.

Russo CAM, Takezaki N and Nei M (1996). Efficiencies of different genes and different ree-building methods in recovering a known vertebrate phylogeny. Mol. Biol. Evol. 13: 525-536.

Sambrook J and Russel DW (2001). Molecular Cloning: A Laboratory Manual. Cold Spring Harbor Laboratory Press. Cold Spring Harbor, New York, 2100.

Smith MF and Patton JL (1993). The Diversification of South American murid Rodents: Evidence from mitochondrial DNA sequence data for the Akodontine Tribe. Biol. J. Linn. Soc. 50: 149-177.

Solari S (2003). A new species of Monodelphis (Didelphimorphia: Didelphidae) from southeastern Peru. Mamm. Biol. 69: $145-152$.

Solari S (2007). New species of Monodelphis (Didelphimorphia: Didelphidae) from Peru, with notes on M. adusta (Thomas, 1897). J. Mammal. 88: 319-329. 
Steiner C and Catzeflis FM (2004). Genetic variation and geographical structure of five mouse-sized opossums (Marsupialia, Didelphidae) throughout the Guiana Region. J. Biogeogr. 31: 959-973.

Tamura K, Stecher G, Peterson D, Filipski A, et al. (2013). MEGA6: Molecular Evolutionary Genetics Analysis version 6.0. Mol. Biol. Evol. 30: 2725-2729.

Tate GHH (1933). A systematic revision of the marsupial genus Marmosa with a discussion of the adaptive radiation of the murine opossums (Marmosa). Bull. Am. Mus. Nat. Hist. 66: 1-250.

Thompson JD, Higgins DG and Gibson TJ (1994). CLUSTAL W: improving the sensitivity of progressive multiple sequence alignment through sequence weighting, position-specific gap penalties and weight matrix choice. Nucleic Acids Res. 22: 4673-4680.

Voss RS and Jansa SA (2003). Phylogenetic studies on didelphid marsupials ii. Nonmolecular data and new IRBP sequences: separate and combined analyses of didelphinae relationships with denser taxon sampling. Bull. Am. Mus. Nat. Hist. 276: 1-82.

Voss RS and Jansa SA (2009). Phylogenetic relationships and classification of didelphid marsupials, an extant radiation of new world Metatherian mammals. Bull. Am. Mus. Nat. Hist. 322: 1-177.

Voss RS, Lunde DP and Simmons NB (2001). The mammals of Paracou, French Guiana: a Neotropical lowland rainforest fauna Part 2. nonvolant species. Am. Mus. Nat. Hist. 263: 1-236.

Voss RS, Gardner AL and Jansa AS (2004a). On the Relationships of "Marmosa" formosa Shamel, 1930 (Marsupialia: Didelphidae), a Phylogenetic Puzzle from the Chaco of Northern Argentina. Bull. Am. Mus. Nat. Hist. 3442: 1-8.

Voss RS, Tarifa T and Yensen E (2004b). An introduction to Marmosops (Marsupialia: Didelphidae), with the description of a new species from Bolivia and notes on the taxonomy and distribution of other Bolivian forms. Bull. Am. Mus. Nat. Hist. 3466: 1-40.

Voss RS, Lunde DP and Jansa AS (2005). On the contents of Gracilinanus Gardner and Creighton, 1989, with the description of a previously unrecognized clade of small Didelphid marsupials. Bull. Am. Mus. Nat. Hist. 3482: 1-34.

Voss RS, Lim BK, Diaz-Neto JF and Jansa SAA (2013). New species of Marmosops (Marsupialia: Didelphidae) from the Pakaraima Highlands of Guyana, with remarks on the origin of the endemic Pantepui mammal fauna. Am. Mus. Nat. Hist. 3778: 1-27.

Xia X (2013). DAMBE5: A comprehensive software package for data analysis in molecular biology and evolution. Mol. Biol. Evol. 30: 1720-1728. 